\title{
Omówienie monografii Jacka Przygodzkiego, Komisje dla usprawnienia administracji publicznej w II Rzeczypospolitej. Studium historycznoprawne, Wydawnictwo Uniwersytetu Wroctawskiego, Wroctaw 2019,
}

SS. 393

\author{
Abstract \\ A Review of Jacek Przygodzki's Monograph Commissions for Jmproving Public \\ Administration in the Second Republic of Poland. A Historical and Legal Study, \\ Wydawnictwo Uniwersytetu Wrocławskiego, Wrocław 2019, 393 p.
}

This text is a review of Dr. Jacek Przygodzki's book, 'Commissions for Improving Public Administration in the Second Republic of Poland. A Historical and Legal Study', which was published by the Publishing House of the University of Wrocław in 2019. This work summarises the author's previous scholarly research in the field of the organization of public administration in interwar Poland. Dr. Przygodzki elaborates the complete history of all five of the commissions for the modernisation of administration, from the time of Poland's regaining its independence to the completion of the work of the Jaroszyński Committee in 1933. The review discusses the structure of the monograph and research methods used by the author, and draws attention to a rich base of sources and extensive literature on the subject. In the conclusion, it is stated that Dr. Przygodzki's book is a scholastically reliable work that gives the reader many interesting bits of information about the organization of public administration in the Second Republic of Poland.

Keywords: The Second Republic of Poland, public administration, commission for improvement, Maurycy Z. Jaroszyński

Slowa kluczowe: II Rzeczypospolita, administracja publiczna, komisja usprawniająca, Maurycy Z. Jaroszyński

Jacek Przygodzki jest historykiem prawa związanym naukowo z Uniwersytetem Wrocławskim. W swoich wcześniejszych badaniach podejmował już wielokrotnie tematykę dotyczącą organizacji i unifikacji systemu administracji publicznej 
w II Rzeczypospolitej ${ }^{1}$. W 2019 r. nakładem E-Wydawnictwa Wydziału Prawa, Administracji i Ekonomii Uniwersytetu Wrocławskiego, ukazała się monografia tego Autora, Komisje dla usprawnienia administracji publicznej w II Rzeczypospolitej. Studium historycznoprawne. Z nutą optymizmu należy zauważyć, że problematyka historii administracji i myśli administracyjnej w Polsce międzywojennej jest coraz częściej obierana jako przedmiot pogłębionej refleksji naukowej, ponieważ obszar ten był przez lata pozbawiony rzetelnego zainteresowania. Analizując dotychczasowy stan badań w tym zakresie, stwierdzamy, że dominują w nim opracowania o charakterze podręcznikowym, które - będąc syntezami - stanowią wybór najważniejszych wątków historii administracji, a nie są ich szczegółową enumeracją².

Pole badawcze, które określił Autor w swojej monografii wypełnia tę lukę, a problematykę, którą przedstawia, uznać należy za interesującą. Wybór tematu pracy jest więc uzasadniony i słuszny. Książka liczy 393 strony, składa się ze wstępu, pięciu rozdziałów podzielonych na podrozdziały, zakończenia, wykazu źródeł i literatury oraz pięciu obszernych aneksów. Każdemu z tych elementów monografii wypada poświęcić nieco więcej uwagi. Do lektury pracy Jacka Przygodzkiego zachęca należycie opracowany Wstęp (s. 11-17). Autor wyczerpująco przedstawia cel monografii, dokonując przeglądu badań w tym zakresie stwierdza, że zagadnienie komisji dla usprawnienia administracji publicznej nie było dotąd przedmiotem szczegółowych studiów. W książce, która jest pracą o charakterze ściśle historycznoprawnym badacz posłużył się metodą historyczną i porównawczą. Założony cel badawczy uwzględnił także konieczność sięgnięcia do metody dogmatycznej. Łączenie metod badawczych jest w literaturze przedmiotu oceniane jako zasadne i pożądane ${ }^{3}$. Należyte wykorzystanie metody dogmatycznej pozwoliło Jackowi Przygodzkiemu do minimum ograniczyć schematyzm opisu kolejno omawianych projektów, będących owocem prac poszczególnych komisji reorganizacyjnych. Właściwa narracja problemu badawczego wymaga zastosowania poprawnego opisu chronologicznego i rzeczowego. Uważam, że Autor podołał temu zadaniu. Określenie ram periodyzacyjnych w naukach historycznoprawnych nastręcza trudności ${ }^{4}$. Trudność ta w recenzowanej monografii związana jest z tym, że proces rozwoju administracji publicznej nie był do końca zbieżny z dziejami politycznymi państwa. Autor

1 Zob. m.in.: J. Przygodzki, Ksztatcenie kandydatów na wyższych urzędników administracji w ankiecie Komisji dla Usprawnienia Administracji Publicznej z 1929 roku, „Krakowskie Studia z Historii Państwa i Prawa" 2015, t. 8, z. 2, s. 185-198; idem, Kilka uwag o Komisji dla spraw oszczędności państwowych z 1920 r., „Acta Universitatis Wratislaviensis. Prawo” 2014, t. 316/2, s. 177-186; idem, Przyczynek do problematyki dekoncentracji w pracach komisji dla usprawnienia administracji publicznej w II Rzeczypospolitej, „Studia z Dziejów Państwa i Prawa Polskiego” 2009, t. 12, s. 227-235. Pełne zestawienie publikacji Autora Czytelnik odnajdzie na oficjalnej stronie internetowej Wydziału Prawa, Administracji i Ekonomii Uniwersytetu Wrocławskiego, https://prawo.uni.wroc.pl (data dostępu: 27.06.2019).

2 Zob. T. Maciejewski, Historia administracji i myśli administracyjnej. Czasy nowożytne i wspótczesne (XVI-XX w.), Warszawa 2013 r.; W. Witkowski, Historia administracji w Polsce 1764-1989, Warszawa 2007; W. Ćwik, Historia administracji, Zamość 2004; J. Malec, D. Malec, Historia administracji i myśli administracyjnej, Kraków 2003; G. Górski, Historia administracji, Warszawa 2002; H. Izdebski, Historia administracji, Warszawa 2002; D. Janicka, Ustrój administracji w nowożytnej Europie. Zarys wykładu, Toruń 2002.

3 Zob. J. Adamus, Metoda porównawcza w historii, Łódź 1955; J. Bardach, Metoda porównawcza w historii państwa i prawa, „Czasopismo Prawno-Historyczne” 1962, t. 14, z. 2, s. 12-16.

4 Zob. m.in. G. Górski, Wokót problemów periodyzacji historii ustroju Polski. Uwagi dyskusyjne, „Czasy Nowożytne" 2001, t. 12, z. 13, s. 5. 
swoje rozważania ujął w latach 1918-1933. Punktem wyjścia jest odzyskanie przez Rzeczpospolitą niepodległości, kiedy to z całą mocą stanął problem budowy rodzimego systemu administracji publicznej, którego zadaniem byłoby zastąpienie pozostałości ustrojowych po państwach zaborczych. Proces ten, co warto zauważyć, jest inicjowany jeszcze przed restytucją państwowości polskiej. Wydaje się tym samym uzasadnione, by Jacek Przygodzki w swoich rozważaniach silniej zaakcentował rolę „organów emancypacyjnych" wyrażających polskie dążenia niepodległościowe. Przykładowo niektóre akty normatywne Rady Regencyjnej możemy zaliczyć do tej kategorii, tym bardziej że nie derogowano ich z systemu prawnego obowiązującego w II Rzeczypospolitej5. Zakończenie prac ostatniej z komisji usprawniających w 1933 r. wieńczy tok wywodu Autora, cezura ta nie budzi wątpliwości. Dalsze prace modernizujące administrację publiczną do 1939 r. nie miały już rozmachu właściwego dla prac komisji, były cząstkowe i wycinkowe w swoim zakresie.

Rozdział I monografii (s. 19-60) stanowi tło historyczne, jest rodzajem wprowadzenia do właściwych rozważań będących przedmiotem opracowania. Uznać należy tę część pracy za wartościową, eksponuje ona element porównawczy, kiedy to Autor przedstawia koncepcje modernizacyjne dotyczące administracji publicznej w wybranych państwach. Interesująco i szczegółowo zaprezentowane zostały liczne propozycje w tym zakresie, jakie pojawiły się w Stanach Zjednoczonych Ameryki. Komparatystyczne omówienie tych zagadnień pozwala Czytelnikowi zestawić polską myśl administracyjną u zarania niepodległości z wiodącymi trendami europejskimi i światowymi. Proces odbudowy państwowości postawił przed ówczesnymi elitami politycznymi i naukowymi wiele trudnych i ambitnych zadań. Wybór najbardziej optymalnego modelu administracji publicznej był jednym z takich wyzwań. Przygodzki wykazał, że debata publiczna w tym czasie była ożywiona i skutkowała pojawieniem się doniosłych osiągnięć kultury prawniczej. Przykładem może być tutaj projekt organizacji administracji, który wyszedł spod pióra Kazimierza Władysława Kumanieckiego.

Rozdziały II-V Autor zbudował w sposób statyczny i analogiczny. Osią centralną prowadzonych w monografii rozważań jest chronologiczna prezentacja pięciu komisji dla usprawnienia administracji publicznej. Badacz słusznie zauważa, że ich główny wysiłek twórczy nakierowany był na eliminację czynników odśrodkowych na rzecz integracyjnych. W każdym z powyższych rozdziałów omówione zostało we właściwej proporcji tło historyczno-polityczne, w jakim powoływano kolejne komisje reorganizujące, ich składy osobowe, organizację prac i rezultaty działań. Autor, analizując materiały archiwalne, źródła drukowane, literaturę przedmiotu, wykazał, że rysem właściwym tych gremiów był wysoki walor merytoryczny prac, który wynikał w dużej mierze z profesjonalnego (eksperckiego) charakteru komisji. Lektura książki dowodzi, że w prace te bezpośrednio lub pośrednio (wykorzystanie ankiet), byli zaangażowani najwybitniejsi luminarze ówczesnej nauki prawa. Wymienić w tym miejscu możemy np.: Stanisława Kasznicę, Michała Bobrzyńskiego, Oswalda Balzera, Władysława Leopolda Jaworskiego. Obraz prac komisji dla usprawnienia administracji publicznej byłby niepełny, gdyby poprzestać tylko na wymienieniu w ich składach osobowych przedstawi-

Zob. J. Bardach, B. Leśnodorski, M. Pietrzak, Historia ustroju i prawa polskiego, Warszawa 1994, s. 451 i nast.; W. Suleja, Próba budowy zrębów polskiej państwowości w okresie istnienia Tymczasowej Rady Stanu, Wrocław 1981. 
cieli doktryny. Autor monografii akcentuje istotny wkład intelektualny włożony przez urzędników praktyków w prace unifikacyjne. Działalność Ludomira Grendyszyńskiego, Jana Żarnowskiego czy Romana Hausnera w pełni to potwierdzają. Uważny Czytelnik zauważy, że ostatni z wymienionych był członkiem wszystkich komisji poza Komisją Trzech. Aktywność publicystyczną Hausnera, którą Przygodzki przytacza obficie, uznać należy za interesujący przejaw działalności popularyzatorskiej prac komisji. Znamiennym rysem II Rzeczypospolitej był wysoki poziom kultury prawniczej i prawnej, lektura recenzowanej monografii w pełni potwierdza taką konstatację. Czytelnik zauważy, że polskie prace reorganizujące administrację publiczną zostały zauważone i wysoko ocenione przez zagraniczne gremia naukowe - IV Międzynarodowy Kongres Nauk Administracyjno Prawnych w Madrycie w 1930 r. (s. 257). Lektura rozdziału II (s. 61-84), poświęconemu Komisji oszczędnościowej, rozdziału III (s. 85-113), omawiającego Komisję gen. Władysława Sikorskiego, rozdziału IV (s. 115-158), prezentującego dwie Komisje z 1926 r., wreszcie rozdziału V (s. 159-255), skupiającego się na pracach Komisji Maurycego Z. Jaroszyńskiego, dowodzi, że wszystkim komisjom postawiono zbliżone do siebie cele prac. Zasługą Autora jest wykazanie, że w toku swej aktywności gremia te modyfikowały zakres rzeczowy swej działalności. Znamiennym przykładem może być tutaj Komisja dla Usprawnienia Administracji Publicznej działająca w latach 1928-1933, która miała wyraźną tendencję do rozszerzającego interpretowania swej misji (s. 164). Zastosowanie w monografii metody historycznej pozwoliło Autorowi uwypuklić elastyczność prac poszczególnych komisji, które pod wpływem potrzeb samej administracji, oczekiwań społecznych, a także, co należy ocenić krytycznie, od formalnych i nieformalnych nacisków politycznych dokonywały zmian w zakresie swojej działalności. Polityczny aspekt możemy z łatwością dostrzec w pracach Komisji Kazimierza Młodzianowskiego (s. 134-158), którą Jacek Przygodzki określa słusznie mianem najbardziej upolitycznionego z wszystkich gremiów usprawniających. Biogramy członków komisji, które zostały pomieszczone w rozdziałach (II-V), uznać należy za intersujące uzupełnienie omawianych w pracy zagadnień. Cechuje je jednak moim zdaniem nierówność stopnia szczegółowości. Czytelnik, zapoznawszy się z każdą z pięciu tytułowych komisji, zauważy, że oparły one swoje prace na przyjęciu stanowiska, iż nowoczesna administracja powinna być strukturą sprawnie zarządzaną, nowoczesną i tanią. Przywołany powyżej Roman Hausner w swoich licznych wypowiedziach, także polemicznych, lansował właśnie taką wizję docelową polskiej administracji publicznej ${ }^{6}$. Postulaty te wraz z upływem czasu nie straciły nic ze swej aktualności, a przywołanie ich w monografii przez Autora dowodzi, że refleksja historyczna powinna być uwzględniana współcześnie.

Zdaniem recenzującego książkę za bardzo interesujący uznać należy najobszerniejszy rozdział V. Komisja dla Usprawnienia Administracji Publicznej, nad którą pochyla się w tej części pracy Przygodzki, wniosła najwięcej dla modernizacji i unifikacji administracji publicznej. Zaakcentowano najdłuższy czasokres jej działania, co było atutem na tle pozostałych raczej incydentalnie funkcjonujących gremiów usprawniających. Podkreślono ambitny zakres rzeczowy jej prac. Doniosłe piętno na działalność

${ }^{6}$ Zob. R. Hausner, Reorganizacja administracji państwowej, „Gazeta Administracji i Policji Państwowej" $1923, \mathrm{nr} 48$. 
tej komisji wywarł jej wiceprzewodniczący Maurycy Z. Jaroszyński. W biogramie tego uczonego (s. 162) zabrakło moim zdaniem uwypuklenia jego pasji polemicznej, żywych dyskusji toczonych z oponentami na łamach współczesnej prasy. Podnoszony w recenzjach zarzut o niewykorzystaniu wszystkich źródeł jest częsty i chyba nie zawsze trafny, niemniej pewien niedosyt stanowi przytoczenie przez Autora w wykazie literatury tylko ośmiu prac Jaroszyńskiego (s. 275). Uczony ten na łamach „,Gazety Administracji i Policji Państwowej” opublikował jedenaście artykułów dotyczących organizacji administracji publicznej. W swej twórczości przedwojennej publikował dużo odnośnie do problematyki samorządu terytorialnego, która także znajdowała się w optyce zainteresowań komisji, którą rzeczywiście kierował. Liczne teksty ogłaszane w „Samorządzie Terytorialnym”, „Samorządzie” czy „Gminie” są tego dowodem?.

Z dużym zainteresowaniem czyta się fragment pracy dotyczący problematyki kształtowania się korpusu urzędniczego w Polsce międzywojennej (s. 167-187), zagadnienie to stało się przedmiotem żywego zainteresowania współczesnych badaczy ${ }^{8}$. Pochwalić należy Autora za szczegółową prezentację ankiet rozesłanych przez gremium Jaroszyńskiego do przedstawicieli nauki prawa. Wypowiedzi uczonych tego formatu, co Oswald Balzer, Ludwik Ehrlich, Kazimierz Władysław Kumaniecki czyta się z niekłamaną przyjemnością i podziwem. Za godne chwili refleksji uznać należy zaprezentowane Czytelnikowi ówczesne propozycje dotyczące organizacji ustroju miasta stołecznego Warszawy (s. 229-237), chociażby dlatego, że we współczesnej debacie publicznej zagadnienie to powraca co czas jakiś. Intersująca była propozycja utworzenia kartoteki bibliograficznej, będącej rezerwuarem danych dla dalszych prac studyjnych nad usprawnieniem administracji publicznej. Postulowano także, co ocenić należy in plus, powołanie nowego organu, jakim miała by być komisja kodyfikacyjna czuwająca nad legislacyjnym poziomem prac reorganizujących i unifikujących administrację. Dostrzegam $\mathrm{w}$ tej inicjatywie refleks nawiązujący do działającej niemal od początku niepodległości Komisji Kodyfikacyjnej Rzeczypospolitej Polskiej ${ }^{9}$. Interesujące ustalenia przedstawia Jacek Przygodzki odnośnie do zagadnień dekoncentracji administracji, które zajmowały poczesne miejsce w pracach Komisji Jaroszyńskiego (s. 225-229).

Monografię podsumowuje syntetyczne zakończenie (s. 257-265), zawierające wszystkie elementy właściwe dla tej części pracy. Na uwagę zasługuje obszerna nota bibliograficzna i bogata podstawa źródłowa monografii (s. 267-286). Zakres analizowanych w pracy źródeł powinien być zbieżny z kwestionariuszem pytań badawczych, uważam, że Autor sprostał temu wymogowi. W zgromadzonej literaturze przedmiotu dominują prace polskojęzyczne, odnajdziemy jednak kilka prac w języku angielskim i niemieckim. W rekonstrukcji dziejów komisji dla usprawnienia administracji publicznej w II Rzeczypospolitej istotną rolę odegrały zespoły archiwalne znajdujące się mię-

7 Zob. A. Rychły-Mierzwa, Maurycy Zdzisław Jaroszyński (1890-1974). Działacz samorzadowy, polityk i naukowiec, Kraków 2007, praca doktorska przechowywana w Archiwum Uniwersytetu Jagiellońskiego w Krakowie. Autor monografii zamieszcza tę pracę w wykazie literatury, ale nie uwzględnia pełnego przedwojennego zestawienia dorobku Jaroszyńskiego ujętego w powyższej pracy, s. 333-339.

${ }^{8}$ Zob. m.in. M. Krzymkowski, Kwalifikacje zawodowe urzędników w II Rzeczypospolitej, „Czasopismo Prawno-Historyczne” (CPH), 2015, t. 67, z. 2, s. 97-110; J. Stelina, Prawo urzędnicze w II Rzeczypospolitej, „Gdańskie Studia Prawnicze” 2006, t. 15, s. 334; B. Kuś, Stużba cywilna w okresie II Rzeczypospolitej, „Roczniki Nauk Prawnych” 2014, t. 24, nr 1, s. 146-148.

${ }^{9}$ Zob. S. Grodziski, Komisja Kodyfikacyjna Rzeczypospolitej Polskiej, CPH, 1981, t. 33, z. 1, s. 47-81. 
dzy innymi w Warszawie, Wilnie i Jenie. W monografii Autor zamieścił pięć aneksów (s. 287-393), ściśle związanych z głównym tekstem pracy. Ujęto w nich akty normatywne uchwalone lub przygotowane przez poszczególne chronologicznie gremia reorganizujące. Obecność aneksów w książce uznać należy za w pełni uzasadnione z uwagi na to, że prezentują one dorobek komisji w praktyce. Warto zauważyć, że w tytule monografii Jacek Przygodzki użył dla opisu wszystkich pięciu komisji zbiorczego terminu usprawniające, podczas gdy terminu tego w rzeczywistości użyto tylko odnośnie do komisji działającej w latach 1928-1933. Tym samym tytuł może wydawać się nie do końca ścisły, choć rzeczywiście zakres rzeczowy prac komisji polegać miał na usprawnieniu administracji publicznej.

Recenzowana książka napisana jest poprawną polszczyzną, wartość naukowej analizy ocenić należy wysoko. Słowa uznania należą się E-Wydawnictwu Wydziału Prawa, Administracji i Ekonomii Uniwersytetu Wrocławskiego za staranną korektę tekstu. Pojawiają się w monografii nieliczne błędy. Autor używa nieprawidłowej nazwy Stanów Zjednoczonych Ameryki (s. 19). W oficjalnej nazwie państwa nie ma mowy o Ameryce Północnej ${ }^{10}$. W toku prowadzonych rozważań użyto określenia „sejm wydał ustawę" (s. 43), podczas gdy ustawy są uchwalane. Powyższe uwagi nie deprecjonują wartości opracowania Jacka Przygodzkiego, które będzie elementem dorobku nauk historycznoprawnych w zakresie badań nad ustrojem administracji publicznej w II Rzeczypospolitej. Zdaniem piszącego te słowa opracowanie Jacka Przygodzkiego spełnia wymóg dobrej monografii, zasługując w pełni na miano rzetelnej pracy naukowej.

10 Zob. M. Sczaniecki, Powszechna historia państwa i prawa, Warszawa 1995, s. 326. 